\title{
KEMAJUAN ISLAM PADA MASA KEKAISARAN TURKI USMANI
}

\author{
Mami Nofrianti \\ LAIN Batusangkr, mami_nofrianti@gmail.com \\ Kori Lilie Muslim \\ IAIN Bukittinggi, liliemuslimkori@gmail.com
}

Diterima: 30 Januari 2019

Direvisi: 2 Mei 2019

Diterbitkan: 30 Juni 2019

\begin{abstract}
This paper discusses the progress of Islam in the Ottoman Empire. The purpose of this paper is to describe how progress has been made for the progress of the Ottoman Turks in the development of Islam. The problem to be answered in this paper is: What is the background of the emergence of the Ottoman government and the progress achieved by the Ottoman Empire. This writing uses a historical approach, with descriptive analysis method. In this paper, it is found that the background of the emergence of the Ottoman government began with the return of Sultan Ala ad-Din II from the Seljug Rum Ertoghul who led the army against the Roman army and then won. With this victory, Sultan Ala ad-Din gave Erthogul a gift, an area bordering Byzantium. Then be built the land and expanded his territory to Byzantium. Erthogul had a child named Usman who was born in 1258 AD That Usman name was taken as the name of the Ottoman Empire. The progress achieved by the Ottoman Empire included developments in the field of thought in the military and government fields, as well as in the fields of science and culture, as well as in the religious fields
\end{abstract}

Keywords: Islam, Progress, Ottoman Turkey

\begin{abstract}
Abstrak
Tulisan ini membahas tentang kemajuan Islam pada masa kekaisaran Turki Usmani. Tujuan tulisan ini adalah untuk mendeskripsikan bagaimana kemajuan demi kemajuan yang dicapai Turki Usmani dalam dalam perkembangan Islam. Permasalahan yang ingin dijawab dalam tulisan ini adalah: Bagaimana latar belakang munculnya pemerintahan Turki Umani dan kemajuan-kemajuan yang dicapai Turki Usmani. Penulisan ini menggunakan pendekatan sejarah, dengan metode deskriptif analisis. Dalam tulisan ini, ditemukan bahwa latar belakang munculnya pemerintahan Turki Usmani bermula dari balas budi Sultan Ala ad-Din II dari Turki Saljuk Rum Ertogbul yang memimpin pasukan perang melawan tentara Romawi dan kemudian menang. Dengan kemenangan ini, maka Sultan Ala ad-Din memberi hadiah kepada pasukan Erthogul, sebuah wilayah yang berbatasan dengan Bizantium. Kemudian ia membangun tanah itu dan memperluas wilayah kekuasaannya ke Bizantium. Erthogul mempunyai anak yang bernama Usman yang labir pada tabun 1258 M. Nama Usman itulah yang diambil sebagai nama kerajaan Turki Usmani. Kemajuan yang dicapai oleh Turki Usmani meliputi perkembangan dalam bidang pemikiran dalam bidang kemiliteran serta pemerintahan, juga bidang ilmu pengetabuan dan kebudayaan, serta bidang keagamaan.
\end{abstract}

Kata Kunci: Islam, Kemajuan, Turki Usmani 


\section{PENDAHULUAN}

Masa dinasti Umayyah dan masa dinasti Abbasiyah adalah masa keemasan bagi Islam, setelah keruntuhan Baghdad pada 1258 M. Sehingga hal ini menyebabkan hancurnya dan runtuhnya peradaban Islam dan masa ini adalah masa-masa yang amat pedih bagi dunia Islam dalam sejarah peradaban Islam. Masa-masa sulit ini dialami oleh Islam menjelang abad $16 \mathrm{M}$. Namun peradaban Islam mulai bergairah kembali dengan kemunculan tiga kerajaan besar yag awalnya ditandai oleh munculnya kerajaan Turki Usmani, kemudian Dinasti Syafawi yang berdiri di Persia serta Dinasti Mughal yang didirikan di India. Tiga kerajaan inilah yang mampu membangkitkan kembali peradaban Islam yang telah diluluhlantakkan oleh Hulagu Khan pemimpin pasukan invasi Mongol dan oleh peristiwa Perang Salib yang berkepanjangan yang menyebabkan hancurnya peradaban Islam. Dalam bukunya Harun Nasution menyebut bahwa masa ini diidentifikasikan sebagai masa keemasan jilid II bagi Islam. ${ }^{1}$

Pada masa Turki Usmani, sepanjang abad ke-16 dan 17 adalah masa puncak kejayaan yaitu pada masa kekuasaannya di bawah pemerintahan Sulaiman Al-Qanuni, Bahkan Turki Usmani tergolong salah satu negara terkuat di dunia, imperium multinasional dan multibahasa yang mengendalikan sebagian besar Eropa Tenggara, Asia Barat/Kaukasus, Afrika Utara, dan Tanduk Afrika. Namun pada abad 18 Turki Usmani mengalami kemunduran dan modernisasi hingga abad 19 mengalami kekalahan dan pembubaran. Pada saat Konstantinopel dijadikan sebagai ibu kota dan kekuasaannya atas wilayah yang luas di sekitar cekungan Mediterania, Turki Usmani menjadi pusat interaksi antara dunia Timur dan Barat selama lebih dari enam abad. Kesultanan ini bubar pasca Perang Dunia I, tepatnya pada 1 November 1922. Pembubaran ini berujung pada kemunculan rezim politik baru

${ }^{1}$ Harun Nasution, Pembaharuan dalam Islam. (Jakarta: Bulan Bintang, 1996) di Turki, serta pembentukan Balkan dan Timur Tengah yang baru².

Berdasarkan fenomena tersebut di atas maka perlu kiranya ada upaya untuk menemukan kembali faktor-faktor pendukung kemajuan peradaban Islam. Dengan cara melakukan upaya mengembalikan sejarah perkembangan Islam sehingga kembali mampu survives di tengah masyarakat. Adapun langkah awal dalam upaya menemukan kembali semangat itu, perlu dilihat kilasan historial Islam, mulai dari awal perjalanan Islam hingga Sekarang.

Dengan latar belakang tersebut tulisan ini mencoba untuk menelisik data-data sejarah yang tersedia mengenai sejarah Islam, khususnya kilasan pada kerajaan Turki Usmani sembari melakukan analisis terhadap aspek- aspek yang memberikan pengaruh terhadap dinamika dan sejarah perkembangan lslam pada kerajaan Turki Usmani. Hingga akhirnya mengalami kemunduran.

\section{METODE PENELITIAN}

Penulisan ini menggunakan pendekatan sejarah yaitu berusaha untuk mengungkapkan dan menganalisis terhadap kemajuan Islam pada masa Kekaisaran Turki Usmani yang terdiri dari empat tahap ${ }^{3}$, yaitu:

Pada tahap awal langkah yang dilakukan adalah heuristik, yaitu pengumpulan sumber. Dikumpulkan sumber sebanyak mungkin yang berkaitan dengan permasalahan baik berupa buku-buku, jurnal, maupun media massa yang membicarakan hal terkait.

Langkah selanjutnya, dilakukan kritik sumber, terhadap segala sumber yang telah diperoleh tadi. Dengan melakukan kritik sumber ini menjadi ukuran sejauh mana objektifitas penulis dalam mengelaborasi segenap data atau sumber yang telah diperoleh, dan tentunya mengedapankan prioritas.

2 A. Mikhail, Nature and Empire in Ottoman Egyp. (Cambridge University Press., 2011)

3 D.Abdurrahman, Metode Penelitian Sejarah Islam, Yogyakarta: Ombak, 2012. 
Setelah melakukan kritik sumber, maka pada tahap ini dilakukan sintesis dengan menggunakan teknik interpretasi yaitu penafsiran fakta-fakta yang didapat dari seluruh dokumendokumen ataupun sumber-sumber yang telah didapat. Tahapan ini dituntut kehati-hatian dan integritas penulis untuk menghindari interpretasi yang subjektif terhadap fakta yang lainnya, agar ditemukan kesimpulan atau gambaran sejarah yang ilmiah.

Langkah terakhir adalah historiografi. Dalam hal ini penulis berusaha semaksimal mungkin menyusun, merangkai dan mencurahkan segenap kemampuan untuk mencari sesuatu yang dimaksud, menyusun rangkuman fakta-fakta kemudian menjelaskan dengan ungkapan historis yang rasional.

\section{KONDISI SOSIAL-POLITIK, SOSIO- KEAGAMAAN DAN SOSIO- PENDIDIKAN, DAN EKONOMI}

Dalam perkembangannya ada beberapa hal yang perlu dijadikan pisau analisis berkenaan dengan kondisi sosial politik, sosio-keagamaan, sosio-pendidikan dan ekonomi.

\section{Kondisi Sosial Politike}

Jika dikaji dalam bidang sosial politik kerajaan Turki Usmani adalah merupakan perpaduan antara kebudayaan Persia, Arab dan Bizantium. Seperti halnya kebudayaan Persia yaitu mereka mengadopsi masalah ajaran-ajaran tentang etika dan tata krama dalam kehidupan di Istana. Sementara mereka mendapatkan Organisasi pemerintahan serta prinsip-prinsip kemiliteran dari kebudayaan Bizantium. Dari kebudayaan Arab mereka mendapatkan ajaran tentang prinsip ekonomi, kemasyarakatan. ${ }^{4}$

Adapun kerajaan Turki Usmani berasal dari keturunan suku Kayi bangsa pengembara yang bermukim di wilayah Asia Tengah. Yaitu salah satu suku di Turki Barat yang juga mendapat serbuan dari bangsa Mongol yang sadis. Pendiri

4 R. Aizid, Sejarah Peradaban Islam Terlengkap. (Yogyakarta: Diva Pers, 2015) kerajaan Turki Usmani adalah bangsa Turki dari kabilah Oghuz yang mendiami daerah Mongol dan daerah Utara negeri Tiongkok. Dalam jangka waktu sekitar 3 abad, mereka berpindah ke Turkistan, lalu Persia dan Irak.

Mereka masuk Islam sekitar abad ke-9 M atau $10 \mathrm{M}$ yaitu saat menetap di Asia Tengah. Pada abad ke - $13 \mathrm{M}$, akibat dari kerasnya tekanan serangan bangsa Mongol, bangsa Turki yang dipimpin oleh Ertoghrul melarikan diri menuju Dinasti Saljuk guna mengabdi kepada penguasa, yang saat itu dipimpin oleh Sultan Alauddin II.

Ertoghrul bersama pasukannya bersekutu dengan pasukan Saljuk demi membantu Sultan Alauddin II berperang menyerang Byzantium. Berkat bantuan mereka akhirnya Sultan Saljuk berhasil memenangkan peperangan tersebut. Atas jasa baik tersebut, Sultan Alauddin II memberikan sebidang tanah yang berada di Asia Kecil berbatasan dengan Bizantium sebagai hadiah bagi mereka. Pada tahun 1289 M, Artogol meninggal dunia. Kepemimpinannya diteruskan oleh putranya, Utsman (nama lengkapnya Sultan Utsmani bin Sauji bin Artogol bin Sulaimansyah bin Kia Alp). Ia diyakini sebagai pendiri kerajaan Turki Usmani. Sultan Utsmani memerintah pada tahun 1290-1326 M $^{5}$ setelah Kerajaan Usmani menyatakan kemerdekaan dan berkuasa penuh atas daerah yang didudukinya.

Sebagaimana ayahnya, Utsman sangat berjasa kepada Sultan Alauddin II dengan keberhasilannya menduduki benteng-benteng Bizantium yang berdekatan dengan kota Broessa. Bangsa Mongol menyerang kerajaan Seljuk dan Sultan Alauddin terbunuh pada tahun 1300 M. Kerajaan Seljuk Rum ini kemudian terpecahpecah dalam beberapa kerajaan kecil. Usman pun memproklamirkan secara de facto dan de jure kemerdekaan wilayahnya dengan nama alSulthanah al-Usmaniyah. Kerajaan ini tergolong memiliki masa penguasaan yang relatif panjang,

5 A. Syalabi, "Mausu'ah al -Tarikh al-Islami wa alHadlarah al-Islamiyyah, (1977), 660 
yaitu lebih kurang 625 tahun tepatnya berakhir tahun $1924 \mathrm{M}$, atau sekitar abad ke-20 M. ${ }^{6}$ Selama perkembangannya terdapat 37 sultan yang pernah berkuasa pada Kerajaan Turki Usmani. Turki Usmani merupakan pusat Khilafah Islam, karena merupakan pemerintahan Islam yang terkuat pada masa itu, bahkan merupakan Negara paling besar di dunia. ${ }^{7}$

Turki Usmani mengalami masa keemasan pada masa pemerintahan Sultan Sulaiman I atau lebih dikenal dengan sebutan sultan Agung atau Al Qanuni. Wilayahnya mencapai kawasan yang sangat luas, meliputi daratan Eropa hingga Australia, Mesir, Afrika Utara hingga ke Aljazair dan Asia hingga ke Persia. Sultan Sulaiman I berhasil menyatukan dua kedaulatannya, di laut dan di darat serta menghimpun dua kekuatannya, keduniaan dan keagamaan. ${ }^{8}$

Masa kebesaran kerajaan Turki Usmani juga dicapai pada masa kesultanan Muhammad II yang lebih dikenal dengan gelar al-Fath, gelar alFath ini diperoleh karena Sultan Muhammad II berhasil menaklukkan kota Konstatinopel pada tanggal 28 Mei 1453 M. Dengan jatuhnya Konstatinopel maka nama Konstantinopel beralih menjadi Istanbul. Hal ini merupakan salah satu saksi sejarah tentang kebesaran kerajaan Usmani (Ottoman Empire).

Wilayah kekuasaan kerajaan Usmani di era pemerintahan Sultan Sulaiman al- Qanuni meliputi tiga benua, yaitu Benua Afrika meliputi Mesir, Libia, Tunis serta Aljazair, benua Asia, meliputi Asia Kecil, Armenia, Irak, Suria, Hijaz serta Yaman. dan benua Eropa meliputi Bulgaria, Yunani, Yugoslavia, Albania, Hongaria dan Rumania.

Namun pada akhirnya, karena pemerintahan yang lemah setelah masa Sulaiman 1, serta faktor dari luar yaitu keunggulan lawan

${ }^{6}$ S. A. Mughi, Sejarah Kebudayaan Islam di Turki. Cet. II; (Jakarta: Logos Wacana Ilmu, 1999)

7 A. Al-Usairy, Al-T à $r$ ì khul Isl à m, diterjemahkan oleh Samson Rabman dengan judul " Sejarab Islam ." (Cet. I; Jakarta: Akbar Media Eka Sarana, 2003).

8 A. Kusdiana, Sejarah dan Kebudayaan Islam Periode Pertengahan. (Bandung: CV. Pustaka Setia, 2013). dalam bidang sains dan teknologi, yang mampu menciptakan peralatan modern menyebabkan Turki Usmani mulai mengalami kemunduran serta mengalami beberapa kali kekalahan perang melawan bangsa Eropa. Kekuasaan politik dan militer yang tangguh selama ini mulai mendapat tantangan pada masa Sultan Murad IV (16231640) dengan munculnya kekuatan Barat. Kekalahan militernya di Eropa dan India, menurut Abdullahi Ahmed an- $\mathrm{Na}^{\text {ee im merupakan }}$ konsekwensi yang harus diterima dinasti ini akibat kemerosotan agama dan budaya, penyimpangan dari tradisi dan korupsi. ${ }^{9}$

Dari penjabaran di atas dipahami bahwa Para pemimpin Turki Usmani pada masa-masa pertama adalah orang-orang yang kuat, sehingga Turki Usmani mampu melakukan ekspansi dengan cepat dan luas. Namun demikian menurut Badri yatim bahwa keunggulan dan kemajuan Turki Usmani dalam mecapai masa keemasannya, bukan semata-mata karena keunggulan para pemimpinnya tetapi ditunjang oleh beberapa keunggulan lainnya. Yang terpenting diantaranya adalah keberanian, ketangguhan, keterampilan dan kekuatan militernya yang sanggup bertempur kapan dan di mana saja.

Kekuatan militer Turki Usmani mulai diorganisir dengan baik ketika terjadi kontak dengan Eropa dibawah kekuasaan Sultan Orkhan. Dalam bidang militer dilakukan perombakkan besar-basaran. Dilakukam pembaruan dengan memutasi personil-personil pimpinan, perombakan dalam keanggotaan dengan memasukkan non-Turki sebagai anggota bahkan anak-anak Kristen diterima menjadi tentara, mereka diasramakan dan dibimbing dalam suasana Islam. Sehingga terbentuklah kelompok militer baru yang bernama Jenissari atau Inkasyiriah. Pasukan Jenissari dapat mengubah Negara Usmani menjadi negara dengan kekuatan militer yang sangat disegani oleh lawan-lawan politik Sultan.

9 A. A. an-N. "Im, Islam dan Negara Sekuler, mengasosiasikan Masa Depan Syariah. (Cet.I; Bandung: PT. Mizan Pustaka, 2007) 
Di samping Jenissari terdapat pula tentara kaum feodal yang dikirim untuk pemerintahan pusat yang disebut militer Taujiab ${ }^{10}$. Dengan adanya pasukan militer yang kuat dan tangguh serta angkatan laut yang hebat, maka kekuatan militer Usmani mampu menaklukkan wilayah yang amat luas yang terbentang dari Asia, afrika dan Eropa. Adapun penyebab dari keberhasilan Turki Usmani juga adalah karena memiliki jiwa pemberani, tegas, disiplin dan patuh terhadap aturan. Ini merupakan watak alami yang diwarisi dari nenek moyangnya di Asia Tengah serta motivasi jihad yang diajarkan oleh Al-Quran.

Bagaimana kondisi Turki Usmani setelah runtuhnya kekuasaan khalifah Turki Usmani atau yang dikenal dengan Dinasti Ottoman? Diberitakan oleh Ali Farkhan Tsani, bahwa sejak runtuhnya khalifah Turki Usmani, 1924 M oleh Musthafa Kemal Pasha, membubarkan sistem Khalifah dalam sidang Dewan Perwakilan Rakyat Nasional. Bahkan Musthafa Kemal Pasha juga menghapus sistem pemerintahan Islam yang telah berjalan ribuan tahun tersebut dari khilafah Usmaniyyah diganti dengan Negara Turki Sekuler.

Dalam perkembangannya di abad 21, dalam analisa orientalis Barat, menyebutkan khilaf yang selama ini dianggap sebagai raksasa tidur kini tengah menggeliat. Sinyal kebangkitan khilafah menuju 100 tahun kebangkitannya sejak 1924 adalah secercah harapan kejayaan Islam dalam bingkai persatuan dan kesatuan umat Islam yang membawa misi rahmatan lil "alamin.

\section{Kondisi Sosio-Keagamaan}

Kesultanan Turki Usmani memegang dua kekuasaan, Pertama, temporal power yaitu kekuasaan politik atau urusan pemerintahan disimbolkan dengan gelar Sultan dan Kedua, Spiritual power yaitu kekuasaan agama atau yang mengurusi masalah agama disimbolkan dengan gelar khalifah. Oleh karena itu, dalam bidang keagamaan penguasa sangat terikat dengan syariat Islam.Ulama mempunyai otoritas yang tinggi dalam negara dan

${ }^{10}$ A. Salabi, Sejarah dan Kebudayaan Islam: Imperium Turki Usmani. Jakarta: Kalam Mulia, 1988 masyarakat. Para ulama yang diketuai syakh alIslam atau mufti--sebagai salah seorang pejabat yang mempunyai wewenang menyampaikan fatwa resmi mengenai kebijaksanaan (policy) sultan dan problematika keagamaan. ${ }^{11}$ Kegiatan tarekat berkembang pesat. Al-Bektasyi dan al-Maulawy merupakan dua yang paling besar dari beberapa aliran tarekat.Tarekat Bekstasy sangat berpengaruh dikalangan tentara Yennisery, sedangkan tarekat Maulawy berpengaruh besar di kalangan penguasa.

Sufisme pada masa itu digandrungi oleh umat Islam dan berkembang pesat.Keadaan frustasi yang merata di kalangan umat karena hancurnya tatanan kehidupan, akibat konflikkonflik internal dan eksternal mengakibatkan orang kembali kepada Tuhan. Madrasahmadrasah yang ada diwarnai dengan nuansa sufistik dengan dijadikannya sebagai zawiyahzawiyah untuk mengadakan riyadhah, merintis jalan untuk kembali kepada Tuhan di bawah bimbingan otoritas mursyid. Dengan demikian maka berkembanglah berbagai sistem riyadhah untuk menuntun para murid, inilah yang kemudian menjadi dan disebut tarekat.

Sampai batas ini maka Fazlur Rahman seperti yang tertuang dalam Islam and Modernity Trans Formation of Antropology Intelectual Tradition bahwa Turki Usmani pada masa tersebut digambarkan sebagai berikut:“... di sebagian besar pusat-pusat sufi terutama di Turki, kurikulum akademis terdiri hampir seluruhnya buku-buku tentang sufi. Di Turki waktu itu terdapat beberapa tempat khusus Methnevikhana, di mana matsnawi-nya Rumi merupakan satusatunya buku yang diajarkan. Lebih jauh lagi, isi dan karya tersebut yang sebagian besar dikuasai pantheisme adalah bertentangan secara tajam dengan lembaga-lembaga pendidikan ortodoks karena itu timbullah suatu dualisme spiritual yang tajam dan berlarut-larut antara madrasah dan balaqah. Ciri khas dari fenomena ini adalah

${ }^{11}$ H. Bakry, "Pedoman Islam di Indonesia." Cet. V; (Jakarta: UI-Press, 1990), h. 326 
melimpahnya pertanyaan-pertanyaan sufi yang taubat setelah menemukan jalan...."12

Menurut penulis bahwa mengatakan wacana sosio-keagamaan yang berkembang di Turki Usmani menjadi sebab kemunduran pendidikan Islam, adalah kesimpulan yang terlalu simpel bila diletakkan dalam kerangka dan ruang sosiologi. Hal ini mengingat permasalahan kemunduran juga tidak bisa dilepaskan dari konteks dinamika sosial masyarakat Turki Usmani pada masa itu.Implikasi terpenting dari situasi di atas adalah semakin surut dan hilangnya tradisi keilmuan di dunia Islam yang berkembang sebelumnya pada masa kejayaan Islam (Umayyah dan Abbasiyah).Lebih dari itu, dinamisme,kreativitas, progevitas serta kebebasan berfikir dan berinvestigasi pun semakin surut. Masyarakat di kerajaan Turki Usmani terus hidup dalam epistemology, meminjam istilah Muhammad Arkoun, thinkable. Dan berawal dari menyerahnya unsur-unsur masyarakat ke dinamisme dan kebebasan pada konsep-konsep yang bersifat statis dan ortodoktif inilah obor keilmuan meredup di kerajaan Turki Usmani dan baru dinyalakan pada etape kepemimpinan Sultan Ahmad III dan kemudian dilanjutkan oleh Sultan Mahmud II (1808-1839 M).

\section{Kondisi Sosio-Pendidikan Islam}

Pada dasarnya proses pendidikan Islam di kerajaan Turki Usmani sebenarnya telah berlangsung sepanjang perkembangan sosial politik dan sosio-keagamaan. Maka untuk dapat mengetahui dinamika kehidupan serta kecenderungan masyarakat dan kebudayaan yang dihasilkannya pada suatu kurun waktu tertentu, cara paling cepat adalah dengan melihat kecenderangan pola hidup para penguasanya. Metode ini akan memperoleh validitas lebih tinggi jika dipergunakan pada model-model perkembangan masyarakat di bawah pemerintahan yang bersifat monarki. Dalam

12 F. Rahman, Islam and Modernity Ttans Formation of Antropology Intelectual Tradition diterjemabkan oleb Absin Mubammad, Islam Modernis tentang Transformasi Intektual. Bandung: Pustaka, 1985 konteks kajian ini, untuk melihat dinamika kehidupan sosio-pendidikan akan dimulai dengan melihat sikap para sultan sebagai kepala pemerintahan di kerajaan Turki Usmani, terhadap pendidikan dan pengembangan keilmuan secara umum.

Institusi pendidikan pada masa Turki Usman mula-mula didirikan oleh Sultan Orkhan (1326-1359). ${ }^{13} \quad$ Sistem pengajaran yang dikembangkan adalah menghafal matanmatanmeskipun murid tidak mengerti maksudnya, seperti menghafal matan Taqrib, matan Sultan, matan al-Jurumiah, matan Alfiah, dan lain-lain. Para muridmempelajari syarahnya setelah menghafal matan itu, kadang-kadang serta khasiyahnya.Sedangkan Ilmu pengetahuan keislaman seperti fiqih, tafsir, ilmu kalam dan lainlain tidak mengalami perkembangan. Kebanyakan penguasa Usmani cenderung bersikapfanatik dan taqlidterhadap suatu mazhab bahkan mereka menentang mazhab yang lain. Melihat kondisi ini maka Khoirul Anam dalam tulisannya yang berjudul Melacak Paradigma Pendidikan Islam: Sebuah Upaya Menuju Pendidikan yang Memberdayakan, mengemukakan sebagai berikut:"“....seiring dengan kemunduran Islam, terutama setelah kejatuhan Abbasiyah di Bagdad tahun $1258 \mathrm{M}$, pendidikan dalam dunia Islam pun ikut mengalami kemunduran dan ke-jumud-an. Sehingga, pendidikan tidak lagi mampu menjadi sebuah 'sarana pendewasaan' umat. Dengan kata lain, sebagaimana dinyatakan Fazlur Rahman, pendidikan menjadi tidak lebih dari sekedar sarana untuk mempertahankan dan melestarikan nilai-nilai 'lama' (tradisional) dari ancaman yang akan mengakibatkan runtuhnya tradisi Islam, khususnya 'standar' moralitas Islam. Yang ditakutkan pendidikan tidak mampu lagi menjadi sebuah proses intelektualisasi yang merekonstruksi paradigma (pola pikir) peserta didik melalui interpretasi secara continue dengan

13 A. S. Sulaiman, Tarikh al-Turki fi Asia al-Wustha Ajib Thabir, Perkembanga Peradaban di Kawasan Dunia Islam: Melacak Akar-akar Sejarah, Sosial, Politik dan Budaya Umat Islam (Jakarta: Ra. Mesir: Maktabah Angelo, 1989 
berbagai disiplin ilmu sesuai perkembangan jaman. Akibatnya, pendidikan Islam melakukan proses 'isolasi' diri sehingga pendidikan Islam akhirnya termarginalisasi dan terhadap perkembangan pengetahuan maupun tekhnologi.

Namun lebih lanjut dugaan Khairul Anam di atas sepenuhnya tidak tepat, setelah penulis mencermati berbagai data yang diperoleh, sebenarnya di dunia Islam pembaharuan pendidikan pertama kali dimulai di kerajaan Turki yaitu sekitar awal abad ke-17 M. Sebagaimana telah disinggung di muka fakor yang melatar belakangi gerakan pembaharuan pendidikan bermula pada kekalahan-kekalahan Kerjaan Usmani dalam peperangan dengan Eropa. Kekalahan tentara Turki pada pertempuran di dekat Wina memaksa Turki menandatangi perjanjian Carlowitz pada tanggal 26 Januari 1699 $\mathrm{M}$, yang berisi penyerahan daerah Hongaria kepada Austria, daerah Podolia dan Ukraina kepada Polandia, daerah Azov kepada Rusia, Transyania kepada Hopsburg, dan wilayah Morca kepada Venetia.

Akibat dari kekalahan demi kekalahan yang dihadapi oleh kerajaan Turki Usmani hal ini menyebabkan Sultan Ahmad III amat prihatin dan melakukan ibda' bi nafsi ini terjadi pada17031730 M. Mengapa Kerajaan Turki Usmani selalu mengalami kekalahan? Hal inilah yang akhirnya menumbuhkan sikap serta semangat baru dalam diri kerajaan Turki Usmani untuk lebih bersikap arif dan bijaksanaterhadap keberadaan bangsa Barat. Sehingga Barat tidak lagi harus dijauhi serta dianggap sebagai musuh. Menurut Sultan Ahmad III jika umat muslim ingin mendapatkan kemajuan, untuk mengejar ketertinggalan Islam dari Barat maka mereka harus mampu menghargai serta mau menjalin kerja sama dengan bangsa Barat.

Langkah awal yang harus diambil, untuk mengamati keunggulan Barat maka dilakukan dengan cara pengiriman duta-duta ke Eropa, dan menyampaikan hasil-hasil penelitian tersebut kepada sultan. Sehingga satu implikasi dari adanya penelitian tersebut muncul ide dari sultan untukmendirikan sekolah Teknik Militer yang mengajarkan taktik, strategi, serta teknik militer.

Selain militer, Turki mengembangkan ilmu pengetahuan dengan cara mendirikan percetakan Istambul pada tahun 1727 M. sebagai cara mempermudah acces buku-buku pengetahuan, mencetak buku-buku tentang ilmu kedokteran, ilmu kalam, ilmu pasti, astronomi, sejarah, kitab hadis, fikih, dan tafsir. ${ }^{14}$ Pada $1717 \mathrm{M}$ berdiri lembaga terjemah yang bertugas untuk menerjemahkan ke dalam bahasa Turki bukubuku dalam berbagai bidang ilmu pengetahuan.

Sultan Ahmad III melakukan upaya pembaruan pendidikan lebih diupayakanuntuk menciptakan satu lembaga pendidikan yang mengajarkan ilmu-ilmu yang disesuaikan dengan kebutuhan masyarakat, bangsa dan negara. Hal ini terus berlanjut sampai Sultan Ahmad III wafat, selanjutnyaupaya ini diteruskan oleh Sultan Salim III.

Sultan Salim III (1789-1807 M),membuat rencana pembaruan yang meliputi perluasan sistem perpajakan, pembentukan korp militer baru, dan pelatihan untuk mendidik para kader bagi rezim baru, yang dikenal dengan program pembaharuan dengan namaNizam Jadid. Pada kenyataannya rencana yang telah disusun dan disampaikan oleh Sultan Salim ternyata tidak mendapat dukungan para ulama dan kelompok militer Yeniseri, yang akhirnya ia sendiri menjadi korban rencana pembaharuan tersebut. Sultan Salim III digulingkan pada tahun 1807 M. Meskipun demikian, program pembaharuan tersebut tetap dapat terealisasi yaitu pada masa pemerintahan periode Sultan Mahmud II, Tanzimat dan Usmani Muda.

Berikut ini adalah ulama-ulama yang terkenal pada masa Turki Usmani ${ }^{15}$ :

14 A. S. Sulaiman, Tarikh al-Turki fi Asia al-Wustha Ajib Thahir, Perkembanga Peradaban di Kawasan Dunia Islam: Melacak Akar-akar Sejarah, Sosial, Politik dan Budaya Umat Islam (Jakarta: Ra. Mesir: Maktabah Angelo, 1989.

${ }^{15}$ H. Nasution, Islam Rasional: Gagasan dan Pemikiran. Bandung: Mizan, 1997 


\begin{tabular}{|c|c|c|c|}
\hline $\begin{array}{c}\mathbf{N} \\
\mathbf{0}\end{array}$ & Nama Ulama & $\begin{array}{c}\text { Wafa } \\
t \\
\text { Tahu } \\
n\end{array}$ & Karya \\
\hline 1 & $\begin{array}{l}\text { Syaikh Hasan bin Ali Ahmad al- } \\
\text { Syabi'iy (al- Madabighy) }\end{array}$ & $\begin{array}{l}1179 \\
\mathrm{H} / 17 \\
56 \mathrm{M}\end{array}$ & $\begin{array}{l}\text { Khasiy } \\
\text { ab } \\
\text { Jam'ul } \\
\text { dan } \\
\text { Syarah } \\
\text { al- } \\
\text { Jurmiy } \\
\text { ab }\end{array}$ \\
\hline 2 & Syamsuddin Ramali & $\begin{array}{l}1004 \\
\mathrm{H} / 15 \\
95 \mathrm{M}\end{array}$ & $\begin{array}{l}\text { Nihaya } \\
b\end{array}$ \\
\hline 3 & Ibn Hajar al-Haijsyamy & $\begin{array}{l}975 \\
\mathrm{H} / 15 \\
67 \mathrm{M}\end{array}$ & Tubfa \\
\hline 4 & $\begin{array}{l}\text { MuhammadbinAbdurRazaq,Mur } \\
\text { thadhodal-Husaini al-Zubaidi }\end{array}$ & $\begin{array}{l}1205 \\
\mathrm{H} / 17 \\
90 \mathrm{M}\end{array}$ & $\begin{array}{l}\text { Sejara } \\
\text { h al- } \\
\text { Qamus } \\
\text { ' } \\
\text { berna } \\
\text { ma } \\
\text { tajjul } \\
\text { Urusy }\end{array}$ \\
\hline 5 & $\begin{array}{l}\text { Syaikh Hasan al-Kafrawy al-safiy } \\
\text { al-Azhary }\end{array}$ & $\begin{array}{l}1202 \\
\mathrm{H} / 17 \\
87 \mathrm{M}\end{array}$ & $\begin{array}{l}\text { Syarah } \\
\text {-syarah } \\
\text { dan } \\
\text { khaisir } \\
\text { ob- } \\
\text { khaisir } \\
\text { ob }\end{array}$ \\
\hline 6 & $\begin{array}{l}\text { Syaikh Muhammad bin Ahmad } \\
\text { bin arfah al-Dusuqy al-maliki } 9\end{array}$ & $\begin{array}{l}1230 \\
\mathrm{H} / 18 \\
14 \mathrm{M}\end{array}$ & $\begin{array}{l}\text { Ahli } \\
\text { filsafat } \\
\text { dan } \\
\text { ilmu } \\
\text { falak } \\
\text { serta } \\
\text { ilmu } \\
\text { ukur }\end{array}$ \\
\hline
\end{tabular}

Sementara perpustakaan yang termasyur pada masa Turki Utsmani pada 1300-1808 M adalah:

\begin{tabular}{|c|l|l|c|}
\hline No & Nama Perpustakaan & Tempat & Koleksi Buku \\
\hline 1 & Sultan Muhammad II & Istambul & 1537 \\
\hline 2 & Sultan Sulaiman & Istambul & 803 \\
\hline 3 & Qallij Ali Basya & Istambul & 752 \\
\hline 4 & Haffiz Ahmad Basya & Istambul & 412 \\
\hline 5 & Qiyuberilly & Istambul & 1448 \\
\hline 6 & Sayyid Ali Basya & Istambul & 2906 \\
\hline 7 & Ibrahim Basya & Istambul & 831 \\
\hline 8 & Wallidah Sultan & Istambul & 732 \\
\hline 9 & Basyir Agha & Istambul & 552 \\
\hline 10 & Aya Sofia & Istambul & 1445 \\
\hline
\end{tabular}

\begin{tabular}{|c|l|l|c|}
\hline 11 & Al-Azhar & Istambul & 1099 \\
\hline 12 & Abdul Basya al-'Azam & Istambul & 422 \\
\hline 13 & Utsman Shalits & Istambul & 2421 \\
\hline
\end{tabular}

\section{Kondisi Ekonomi}

Telah disinggung di atas bahwa Turki Usmani adalah negara yang unggul dibidang militer, lebih memperhatikan kemajuan bidang politik dan militer.Dengan demikian kondisi keuangan serta perekonomian turut meningkat serta memberikan andil bagi perkembangan lslam di kerajaan Turki Usmani. Terjadinya peperangan yang berkesinambungan yang menimpa Turki Usmani baik peperangan yang bersifat ofensifekspansif (untuk memperluas wilayah kekuasaan), defensive (mempertahankan diri dari serangan luar) maupun yang bersifat prefentif (untuk memadamkan pemberontakan-pemberontakan dari dalam). Berbagai peperangan ini sangat menguras sumber dana Turki Usmani.

Sebagai konsekuensi logis dari peperangan yang berkepanjangan ini adalah melemahnya sendi-sendi kekuatan kerajaan dibidang militer, administrasi dan lainnya.Peperangan tersebut juga berdampak pada merosotnya perekonomian Turki Usmani karena pendapatan negara berkurang secara drastis sementara belanja negara semakin meningkat untuk membiayai perang.

Akibat perang yang berkesinambungan, tak kunjung usai, berakibat pada lemahnya perekonomian negara, dan tentu juga berakibat kesejahteraan umum menjadi terabaikannya. Keadaan demikian membuat penguasa Turki Usmani lengah sehingga tidak lagi memikirkan apalagi memperhatikan pola pembangunan dan rehabilitasi jalan-jalan, rumah sakit, sekolahsekolah serta prasarana ekonomi seperti pembangunan sektor pertanian, pengairan atau pemeliharaan bendungan, sehingga para petani kehilangan harapan untuk mengembangkan taraf hidup mereka. Kondisi demikian berdampak pada berbagai sektor. 


\section{TURKI USMANI DAN PERANANNYA DALAM PERADABAN ISLAM}

Dalam perkembangannya Turki Usmani mempunyai pengaruh yang sangat beasar terhadap perkembangan peradaban Islam, khususnya dari segi bidang militer. Bidang militer Turki Usmani sangat unggul dan terkenal dengan tentara Jenisarinya yang tangguh. Hal inilah yang sangat berpengaruh terhadap peradaban Islam yang berkembang pada masa itu. Perkembangan peradaban semacan ini adalah salah satu karakter yang dimilki oleh Turki Usmani dalam perkembangan Peradaban Islam.

Dalam perkembangan Turki Usmani yang begitu lama serta dengan segala kemajuankemajuan yang dicapai ini sangat memberikan andil yang besar terhadap peradaban Islam. Sehingga pengaruh peradaban Turki sangat kuat bahkan sampai abad ke-13 bahasa Arab menjadi bahasa resmi bagi negara di Asia Kecil meskipun Turki tidak mengikuti peradaban Arab secara total. Demikian juga halnya peradaban Arab tidak terlepas dari pengaruh peradaban-peradaban yang berinteraksi dengannya,tidak terkecuali Turki.

Berdasarkan penjelasan di atas dapat disimpulkan bahwa peran Turki Usmani dalam perkembangan peradaban Islam sangat kuat pengaruhnya serta tidak dapat dikesampingkan. Dengan luasnya wilayah kekuasaan yang membentang dari Asia sampai Eropa dalam rentang waktu selama kurang lebih 625 tahun, maka terjadilah interaksi peradaban dengan berbagai wilayah yang berada di bawah kekuasaan Turki dan saling mempengaruhi, sehingga peradaban yang lebih kuat banyak memberikan pengaruh terhadap peradaban yang lebih lemah.

Namun di era abad 21 ini, seperti yang diungkapkan Reuters, Turki masih menghadapi jalan panjang untuk mengejar ketertinggalannya khususnya dalam pendidikan. Tapi jika dilihat dari jumlah perubahan yang telah terjadi, baik mengenai pendidikan dan persamaan, hal itu sudah luar biasa.

\section{KEMAJUAN YANG TELAH DICAPAI OLEH KERAJAAN TURKI USMANI}

Walaupun sebelumnya sudah disinggung pada peranan Turki Usmani, namun untuk lebih rincinya dapat dipahami sebagai berikut:

\section{Bidang Kemiliteran dan Pemerintahan}

Masa kepemimpinan Artogol sampai Orkhan merupakan masa pembentukan kekuatan militer. Sedangkan, perang dengan Byzantium sebagai awal didirikannya pusat pendidikan dan pelatihan militer yang disebut Jenissari atau Inkisyariyah. Selain itu, Kerajaan Usmani juga membuat struktur pemerintahan, dengan kekuasaan tertinggi di tangan raja,yang dibantu oleh perdana menteri yang membawahi Gubernur. Gubernur mengepalai Daerah Tingkat I. Di bawahnya ada Bupati.

\section{Bidang Ilmu Pengetabuan dan Budaya}

Kebudayaan Kerajaan Turki Usmani merupakan perpaduan ragam kebudayaan, seperti Persia, Byzantium, dan Arab. Dari kebudayaan Persia mereka mengambil ajaran-ajaran tentang etika dan tata karma dalam istana raja. Sedangkan organisasi pemerintahan dan kemiliteran diserap dari Byzantium. Adapun ajaran mengenai prinsipprinsip ekonomi, sosial dan kemasyarakatan, keilmuan, serta huruf diambil dari Arab.

Dalam ilmu pengetahuan, Kerajaan Turki Usmani tidak begitu menonjol. Sebab, mereka lebih fokus pada kegiatan militer. Sehingga dalam khazanah intelektual Islam, tidak ada ilmuan yang terkemuka dari kerajaan tersebut.

\section{Bidang Keagamaan}

Agama dalam tradisi msyarakat Turki mempunyai peranan besar dalam lapangan sosial dan politik. Masyarakat digolongkan berdasarkan agama, dan kerajaan pun sangat terikat dengan syari'at, sehingga fatwa ulama menjadi hukum yang berlaku. Oleh karena itu, ajaran-ajaran tarekat berkembang dan mengalami kemajuan di Kerajaan Turki Usmani. Para mufti menjadi pejabat tertinggi dalam urusan agama sekaligus berwenang memberi fatwa resmi terhadap 
problem keagamaan yang terjadi dalam masyarakat.

Dari penjabaran sebelumnya dapat ditarik dan kembali melihat sejarah bahwa Turki sekuler muncul dari runtuhnya kesultanan Ottoman hal ini menyebabkan terjadinya penghapusan kekhalifahan Islam. Kemudian pada masa Kemal Ataturk sebagai pendiri Turki Modern, ia memperkenalkan sejumlah reformasi yang mengurangi peranan Islam di Negara tersebut. Madrasah ditutup, pelarangan memakai jilbab dan pakaian keagamaan serta azan dirubah dari bahasa Arab ke bahasa Turki serta penerapan undangundang sekuler lainnya.

Pada perkembangan selanjutnya, diketahui bahwa Turki menjadi Negara sekuler dalam beberapa dekade, namun setelah naiknya Tayyip Erdogan, menjadi presiden Turki, Erdoga memutarbalikkan berbagai undang-undang yang diterapkan oleh Attaturk. Bahkan kembali membumikan Islam di Turki.

\section{KESIMPULAN}

Setelah menelaah data-data yang masih sangat terbatas mengenai Kemajuan Islam ma kekaisaran Turki Usmani, dapat disimpulkan sebagai berikut:

Pertama, Kerajaan Turki Utsmani sebagai kerajaan yang mampu bertahan hingga abad ke20. lebih banyak difokuskan pada masalah kemiliteran dan perluasan wilayah. Oleh karena itu berkaitan dengan praktek pendidikan dan kehidupan intelektualnya secara keseluruhan diarahkan untuk memperkokoh stabilitas imperium kerajaan.

Kedua, terdapat hubungan yang sangat intens dan mutualistik serta inter-causalistik antara kepentingan interes militer, keagamaan, kekuasaan, dan pembaharuan dalam bidang pendidikan. Hal ini dapat dipahami, bahwa pada satu sisi militer demikian keras diinjeksikan pada seluruh lapisan dan wiliayah kerajaan demi memperkokoh kekuasaan Turki Usmani dan pada sisilain sosiokeagamaan pihak penguasa sangat terikat dengan syariat Islam dan berkembang pula paham yang berorientasi sufistik.

Upaya pembaharuan yang dilakukan oleh para sultan di atas, sesungguhnya lebih ditujukan menjawab aspirasi tuntutan zaman abad ke-19 M. Misalnya pembaruan Sultan Ahmad III, upaya pembaruan itu lebih banyak ditujukan kepada:

1) Pada pola pemikiran dan sikap yang tadinya anti Barat ke proses kerjasama yang lebih intens dengan cara pengiriman duta-duta ke Eropa;

2) Pendirian sekolah-sekolah modern, seperti Sekolah Teknik Militer

3) Pembentukan percetakan buku, hal ini dilakukan sebagai upaya mempermudah access informasi dari Barat. Dengan demikian, upaya pembaharuan yang dilakukan oleh beberapa Sultan di Kerajaan Turki Usmani di atas, sesungguhnya lebih banyak melakukan pembentukan sistem sebagai jawaban dari beberapa kemunduran yang dialami oleh Kerajaan Turki Usmani.

\section{DAFTAR KEPUSTAKAAN}

Abdurrahman, Metode Penelitian Sejarah Islam. Yogyakarta: Ombak, 2012.

A. A. an-N. " Im, Islam dan Negara Sekuler, mengasosiasikan Masa Depan Syariah. (Cet.I; Bandung: PT. Mizan Pustaka), 2007.

A. Al-Usairy, Al-T à $r$ i khul Isl à m, diterjemabkean oleh Samson Rahman dengan judul "Sejarah Islam.” (Cet. I; Jakarta: Akbar Media Eka Sarana), 2003.

A. Kusdiana, Sejarah dan Kebudayaan Islam Periode Pertengahan. Bandung: CV. Pustaka Setia, 2013.

A. S. Sulaiman, Tarikh al-Turki fi Asia al-Wustha Ajib Thabir, Perkembanga Peradaban di Kawasan Dunia Islam: Melacak Akar-akar Sejarah, Sosial, Politik dan Budaya Umat Islam Jakarta: Ra. Mesir: Maktabah Angelo, 1989.

B. Yatim, Sejarah Peradaban Islam. Edisi I; (Jakarta: PT. Raja Grafindo Persada), 2006 
Nasution,Harun, Pembaharuan dalam Islam. Jakarta: Bulan Bintang, 1996

Nasution,Harun, Islam Rasional: Gagasan dan Pemikiran. Bandung: Mizan, 1997

A.Mikhail, Nature and Empire in Ottoman Egyp. Cambridge University Press., 2011

H. Bakry, "Pedoman Islam di Indonesia." Cet. V; Jakarta: UI-Press, p. 326, 1990.

F. Rahman, Islam and Modernity Ttans Formation of Antropology Intelectual Tradition diterjemabkan oleh Absin Muhammad, Islam Modernis tentang Transformasi Intektual. Bandung: Pustaka, 1985, 1985

R. Aizid, Sejarah Peradaban Islam Terlengkap. Yogyakarta: Diva Pers, 2015, 2015.

Syalabi, Ahmad, "Mausu'ah al -Tarikh al-Islami wa al-Hadlarah al-Islamiyyah," p. 660, 1977

Syalabi, Ahmad, Sejarab dan Kebudayaan Islam: Imperium Turki Usmani. Jakarta: Kalam Mulia, 1988.

S. A. Mughi, Sejarah Kebudayaan Islam di Turki. Cet. II; Jakarta: Logos Wacana Ilmu, 1999 